\title{
Language Learning Strategies Used by Art School ESL Learners
}

\author{
Dalila Ayu Adan, Harwati Hashim* \\ Faculty of Education, Universiti Kebangsaan Malaysia, Bangi, Malaysia \\ Email: `harwati@ukm.edu.my
}

How to cite this paper: Adan, D. A., \& Hashim, H. (2021). Language Learning Strategies Used by Art School ESL Learners. Creative Education, 12, 653-665. https://doi.org/10.4236/ce.2021.123045

Received: February 16, 2021

Accepted: March 26, 2021

Published: March 29, 2021

Copyright $\odot 2021$ by author(s) and Scientific Research Publishing Inc. This work is licensed under the Creative Commons Attribution International License (CC BY 4.0).

http://creativecommons.org/licenses/by/4.0/ (c) (i) Open Access

\begin{abstract}
Language Learning Strategies (LLSs) are important in learning a language especially in learning second and foreign language. Many studies on LLSs have been conducted by scholars around the world that prove the significant impact of employing LLSs in acquiring a second language. In Malaysia, English is regarded as a second language and learnt formally in school as an academic subject from 7 to 17 years old. This paper aims to investigate LLSs used by ESL learners who are artistically talented in an art school. This study is a survey and the data were gathered by administering the Strategy Inventory Language Learning (SILL) questionnaire by Oxford (1990). The questionnaire was given to 77 pupils who are 16 and 17 years old. They study in an art school in Malaysia and they have different talents in arts. They are considered as artistically talented to be enrolled in art school. The data were analysed descriptively. The finding shows that the most employed LLSs by art school ESL learners are Metacognitive Strategy and the least employed LLSs are Compensation Strategy. Most ESL learners in Malaysia are very dependent on teachers and have difficulty in achieving a certain level of fluency. They are not aware of their self-ability to govern self-learning. That is why LLS is very important as it effectively improves learners' proficiency in acquiring the second language. Both teachers and pupils need to be aware of the learners' ability and preference in choosing suitable LLSs. Since most of the previous researches focus on successful and good language learner, more studies need to be carried out to help and guide less successful learners to be at the same par as a good language learner.
\end{abstract}

\section{Keywords}

ESL (English as a Second Language), ESL Learners, Language Learning Strategies, Artistically Talented Students, Art School 


\section{Introduction}

LLS is a part of the language field. It started to develop in the 1970s. There is still a lot more to be explored by scholars and researchers. Previously, research on LLSs emphasizes more on successful language learners. Studies after studies listed the characteristics of a good language learner where the less successful learner is left unattended. However, by identifying good language learners, researchers can distinguish between the two types of learners. Only then guidance can be given to those less successful learners by training them to use suitable and appropriate LLSs. By employing appropriate strategies, learners will be able to improve their proficiency, self-confidence, perception, reception, storage, retention, and retrieval of a language learned (Oxford, 2003; Oxford, 1990). Each language learner differs from the other in so many ways. A group of ESL learners in the same environment taught by the same teacher will not achieve the same level of proficiency at the end of the lesson. By employing LLSs, it will help those language learners to acquire the language better even if the development level isn't the same. As mentioned by Chien (2010), the use of LLSs will help non-native learners to enhance their learning. This is a great opportunity to help ESL learners to improve their experience in language learning and fluency too. Introducing and identifying LLSs to ESL learners definitely will not cause any harm and in return very beneficial. LLSs train learners to be independent. Learners can control, monitor, plan their language learning and towards the end, they should be able to measure their achievement. Cohen (1995) stated that LLSs have an explicit goal of assisting learners in improving their knowledge of a target language. This means that LLSs can be viewed as goal-oriented actions. After a leaner employs all the strategies planned, they should achieve their goal/s at the end of the process. As for the goals, they may differ according to the individual.

In the Malaysian context, English is regarded as a second language which means Malaysian should be able to use and communicate in English. As cited by Thirasanku and Yunos (2014) claims that the function of English was first as an official language and then as a second language. However, a huge number of ESL learners in Malaysia are not able to use the language proficiently. English level of proficiency is quite low and when the pupils enter the tertiary level of education or venture into the working field, they are not able to communicate well in English. The Ministry of Education in Malaysia can foresee this problem. The government has come up with few solutions to solve the problem. One of them is by introducing and implementing CEFR. CEFR is an education framework from Europe and emphasized student-centered learning. It is interesting because CEFR is aligned with LLSs where both promote student-centered learning. It empowers the pupil to govern self-learning. Teachers and educators are aware of CEFR but not all of them are familiar with LLSs. As mentioned previously, LLSs are proven to give a positive impact and help ESL learners to improve their fluency and proficiency. It is important to introduce 
LLSs in the Malaysian education system as it benefits both students and teachers.

This paper focuses on a more specific context of artistically talented students. Vicig (2009) claims that the needs and experience of artistically talented students are currently unknown. There are not many studies highlight the preference of LLSs employed by different types of learner and in this context, the focus is on artistically talented students. In Malaysia, there are special schools that cater to various kinds of students' needs and abilities. As mentioned by Vicig (2009), education practices should be diverse and the individual needs of all students can be met satisfactorily. As a result, a variety kind of schools existed. Examples of schools that we have in Malaysia are sports schools, religious schools, and art schools. These kinds of schools are not as many as daily mainstream schools or boarding schools. These schools cater students who do not perform well in academic but they have other talents. For example, the Malaysian Art School (Sekolah Seni Malaysia) caters to students who are talented in music, drawing, acting, and dancing. In the last 40 years visual art, drama, music, dance, and media have been commonly grouped under the umbrella term The Arts (Vicig, 2009). This statement aligns with the art courses offered in the Malaysian Art School. There are five art schools in Malaysia located at Johor, Kuala Lumpur, Perak, Sabah, and Sarawak. The students who are selected to enroll in this school are mostly weak in academics but they are artistically talented. The minimum academic qualification needed to enroll in this school is to achieve at least a B grade in three subjects out of six and no failures in the Primary School Achievement Test (UPSR) (Malaysian Ministry of Education, 2020). That is why there is a huge need to research the preference and usage of LLSs among ESL learners in art school to help them to improve their proficiency in the second language and achieve good grades in English in the Malaysian Certificate of Education (SPM) examination. Achieving good grades is vital as a prerequisite to further study in tertiary level education. The investigation of the students' preferred LLSs will help the stakeholders to plan and cater to the educational needs of artistically talented students.

Thus, this paper serves as a platform to identify the LLSs used by art school ESL learners in Malaysia. There are two research questions that this study intends to answer, which are:

1) What are the language learning strategies used by ESL learners in an art school

2) What are the language learning strategies used by the artistically talented students according to their art department (talent).

\section{Literature Review}

\subsection{Definition of Language Learning Strategies}

There is a slight difference between learning strategies and language learning strategies. Scholars and researchers might define the terms differently according 
to the context and situation or based on what they encountered when the research is carried out. Everyone in this world surely has undergone a learning process no matter at what age level. No one is born gifted and able to do anything without learning first. To learn something, a person might deploy certain strategy/strategies to achieve the intended goal. As cited by Chien (2010) define learning strategies as various operations that help learners to learn. It is not specified as anything which means as long as a learner deploys a strategy or taking steps to learn something, it is a learning strategy. It applies to any academic field. Whereby, language learning strategies referring to learning and acquiring a language may it be a mother tongue, second language, or foreign language.

O'Malley and Chamot (1990) defined LLSs as techniques that are obtained on purpose to help learners improve in learning a second language. In this context, strategies, techniques, steps, and actions can denote the same thing or at least related. It revolves around what a learner does to be better at learning and acquiring the target language. The most popular definition and widely used in the field is the definition given by Oxford (1990), she mentioned that LLSs are meant to make learning easier, enjoyable, faster, and self-directed. One of the most important criteria in LLSs is the ability to create autonomous learners. Learners can guide and direct their learning. They can control their learning pace whether to make it slower or faster according to their ability and situation. No one can understand a learner better than they. Rather than depending on teachers, learners should be trained to become independent.

Griffiths has defined LLSs as activities chosen by the learner consciously to regulate their language learning. Bayuong, Hashim and Yunos (2019) stated that LLSs may also be regarded as mental activities taken by the learners to understand the process of acquiring another language. This is related to the difference between language learning strategies and language use strategies. LLSs are mental actions and steps taken in learning, understanding, and making sense of a new language learned. It is a thinking process that required our brain to work and digest the input. On the contrary, language use strategy is when a learner uses the target language. It is the act of using and doing it. To conclude, LLSs can be defined as approaches, techniques, methods, or mental steps used by the learners in acquiring a language.

\subsection{Classification of Language Learning Strategies}

LLSs themselves have gone through phases of development. The classification started in the 1970s aligns with the emergence of researches in the LLSs field. Chien (2010), explains that there are at least five scholars who come up with a different type of LLSs classification. With every research carried out, improvisation is made on classification and typology.

As cited by Chien (2010), Brown and Palinscar, and O'Malley et al. share the same idea on LLSs classification. It is divided into three main strategies which are Cognitive strategies, Metacognitive Strategies, and Social-affective strategies. 
Oxford (1990) has improvised the classification by coming up with direct and indirect strategies. There are three strategies under direct strategies and another three strategies under indirect strategies, in a total of six strategies. The strategies under direct strategies are memory, cognitive, and compensation, whereas indirect strategies are metacognitive, affective, and social strategies. There are 19 secondary strategies and 62 specific (tertiary) strategies that learners can choose from. Oxford's LLSs classification can be considered the most famous and widely used because it is detailed and she comes up with a very useful survey which is Strategy Inventory Language Learning (SILL) that is fundamental for teachers and educators in determining and identifying the students preferred LLSs.

\subsection{Why Language Learning Strategies are Important in Acquiring Second Language (English)}

Malaysia is a beautifully mixed country. Several races and ethnicities are living harmoniously in Malaysia. Each race and ethnicity has its mother tongue and the national language is Bahasa Melayu. This brings another issue in which is the status of the English language in Malaysia. It depends on the individual. English may become a second or third language. For example, a Chinese student may speak mandarin as his mother tongue, Bahasa Melayu as a second language, and English as the third language. However, despite learning new languages, acquiring a mother tongue will not be as tough as acquiring a second and foreign language since the nature of the mother tongue is more natural and convenient compared to other types of language. So, by introducing LLSs, it will be convenient for the learners to learn a new language in a more appropriate manner.

LLSs have proved their significant impact in helping learners to improve in learning a new language in the past studies. For example, Bayuong, Hashim and Yunos (2019) stated that the correct approaches and strategies will support learners in the process of language learning. Research after research can prove its significant impact in directing learners from unsuccessful learners to the successful learner. In Malaysia, it will be even more useful as the learner might learn more than two languages.

\subsection{Factors Affecting Language Learning Strategies Used}

As cited by Chien (2010), many factors influence the usage of language learning strategies, it varies from age, sex, attitude, aptitude, motivation, task requirements, learning stage and style, individual differences, cultural differences, and language proficiency. Individuals are born differently and have their characteristics. People might share similarities but definitely, there are also differences. Like and dislikes among people would also differ. The same goes for learners' preference when choosing and using LLSs. An introvert learner might not want to try any social strategies whereby an extrovert learner would be more than happy to deploy social strategies. When needs and situations change the selection of strategies will change accordingly. For example, in completing a group work 
task/assignment, a learner will not have plenty of choices. They have to communicate and deploy social strategies to complete the work given.

Above all, motivation seems to be the most significant factor in the use of LLSs (Rahimi, Riazi, \& Saif, 2008) as cited by Bayuong, Hashim and Yunos (2019). Motivation will drive learners' actions and behavior. Once the learners are motivated, they have the passion and effort to achieve their aim.

\section{Methodology}

This study was conducted using a survey research design through questionnaires adopted from SILL by Oxford (1990). A survey is employed because it is the most suitable way to carry out this research and collect the data needed. The researcher has distributed the questionnaire through google form since the school was closed at that particular time because of the Covid19 pandemic. The questionnaire consists of seven parts which are A (demographic), B (memory strategy), C (cognitive strategy), D (compensation strategy), E (metacognitive strategy), F (affective strategy), and G (social strategy). The total of items asked is 50 items with a 5-point Likert Scale. This questionnaire was administered to a group of purposive sampling. There were 77 respondents age 16 and 17 years old. After the raw data were collected, it is analyzed descriptively using Statistical Package for the Social Sciences (SPSS).

\section{Results and Discussion}

Table 1 is based on the demographic profiles of the respondents. There are 4 items asked which are gender, race, form, and the respondents' art department in the school. The respondents are from the same school. From the table, we can see that more female students $(63.3 \%)$ compared to male students $(36.4 \%)$ took part in answering the questionnaire. Form five students recorded a higher percentage compared to form four students. Meanwhile, for the race, the majority

Table 1. Demographic profiles of the respondents.

\begin{tabular}{lccc}
\hline No. & Item & & $\%$ \\
\hline 1. & Gender & Male & $36.4 \%(28)$ \\
& & Female & $63.6 \%(49)$ \\
\hline 2. & Race & Malay & $97.4 \%(75)$ \\
& & Chinese & $1.3 \%(1)$ \\
3. & Indian & $1.3 \%(1)$ \\
\hline & Form & Four (16 YO) & $39 \%(30)$ \\
& & Five (17 YO) & $61 \%(47)$ \\
\hline 4. & Dance & $37.7 \%(29)$ \\
& Art Department & Theater & $18.2 \%(14)$ \\
& & Music & $31.2 \%(24)$ \\
& & Visual Arts & $13 \%(10)$ \\
\hline
\end{tabular}


of the respondents are Malay. The most important demographic item is the art department enrolled by students in that school because it will answer the second research question. The highest percentage is dance (37.7\%), followed by music (31.2\%), theatre (18.2\%), and the lowest percentage is visual arts (13\%).

\section{RQ 1: What are the language learning strategies used by ESL learners in an art school}

Both research questions are answered using data gathered from the SILL questionnaire. RQ1 is more general whereas RQ2 is more specific but both are looking at artistically talented students' preference in LLSs. The questionnaire is categorized based on 6 constructs that represent 6 strategies under Oxford's classification. The following Tables 2-7 present data that involves meaning, median, and mode. From there we can determine which LLS is used by ESL learners who are artistically talented in that particular art school where the survey is carried out.

All the 6 tables are statistical data obtained from SPSS. Each table represents one construct (strategy) together with the mean for every item. A comparison was made by comparing all 6 mean values to determine the LLSs used by the

Table 2. Memory strategy.

\begin{tabular}{cccccccccc}
\hline & Q1 & Q2 & Q3 & Q4 & Q5 & Q6 & Q7 & Q8 & Q9 \\
\hline N Valid & 77 & 77 & 77 & 77 & 77 & 77 & 77 & 77 & 77 \\
Missing & 0 & 0 & 0 & 0 & 0 & 0 & 0 & 0 & 0 \\
Mean & 3.75 & 3.87 & 3.86 & 3.78 & 3.40 & 2.87 & 3.52 & 3.44 & 3.69 \\
Median & 4.00 & 4.00 & 4.00 & 4.00 & 3.00 & 3.00 & 4.00 & 3.00 & 4.00 \\
Mode & 4 & 4 & 3 & 3 & 3 & 3 & 4 & 3 & 3 \\
\hline
\end{tabular}

Table 3. Cognitive strategy.

\begin{tabular}{ccccccccccccccc}
\hline & Q10 & Q11 & Q12 & Q13 & Q14 & Q15 & Q16 & Q17 & Q18 & Q19 & Q20 & Q21 & Q22 & Q23 \\
\hline N Valid & 77 & 77 & 77 & 77 & 77 & 77 & 77 & 77 & 77 & 77 & 77 & 77 & 77 & 77 \\
Missing & 0 & 0 & 0 & 0 & 0 & 0 & 0 & 0 & 0 & 0 & 0 & 0 & 0 & 0 \\
Mean & 3.71 & 3.92 & 4.05 & 3.74 & 3.52 & 4.05 & 3.73 & 3.48 & 3.70 & 3.84 & 3.65 & 3.57 & 3.32 & 3.53 \\
Median & 4.00 & 4.00 & 4.00 & 4.00 & 3.00 & 4.00 & 4.00 & 3.00 & 4.00 & 4.00 & 4.00 & 4.00 & 3.00 & 3.00 \\
Mode & 3 & 4 & 5 & 3 & 3 & 5 & 4 & 3 & 3 & 3 & 4 & 3 & 3 & 4 \\
\hline
\end{tabular}

Table 4. Compensation strategy.

\begin{tabular}{ccccccc}
\hline & Q24 & Q25 & Q26 & Q27 & Q28 & Q29 \\
\hline N Valid & 77 & 77 & 77 & 77 & 77 & 77 \\
Missing & 0 & 0 & 0 & 0 & 0 & 0 \\
Mean & 3.78 & 3.57 & 3.36 & 2.91 & 3.64 & 3.73 \\
Median & 4.00 & 4.00 & 3.00 & 3.00 & 4.00 & 4.00 \\
Mode & 3 & 3 & 3 & 3 & 3 & 3 \\
\hline
\end{tabular}


Table 5. Metacognitive strategy.

\begin{tabular}{cccccccccc}
\hline & Q30 & Q31 & Q32 & Q33 & Q34 & Q35 & Q36 & Q37 & Q38 \\
\hline N Valid & 77 & 77 & 77 & 77 & 77 & 77 & 77 & 77 & 77 \\
Missing & 0 & 0 & 0 & 0 & 0 & 0 & 0 & 0 & 0 \\
Mean & 4.00 & 3.97 & 4.13 & 4.18 & 3.60 & 4.04 & 4.00 & 3.75 & 4.00 \\
Median & 4.00 & 4.00 & 4.00 & 4.00 & 3.00 & 4.00 & 4.00 & 4.00 & 4.00 \\
Mode & 5 & 5 & 5 & 5 & 3 & 5 & 5 & 3 & 4 \\
\hline
\end{tabular}

Table 6. Affective strategy.

\begin{tabular}{ccccccc}
\hline & Q39 & Q40 & Q41 & Q42 & Q43 & Q44 \\
\hline N Valid & 77 & 77 & 77 & 77 & 77 & 77 \\
Missing & 0 & 0 & 0 & 0 & 0 & 0 \\
Mean & 3.75 & 3.97 & 3.43 & 3.68 & 3.13 & 3.43 \\
Median & 4.00 & 4.00 & 3.00 & 4.00 & 3.00 & 3.00 \\
Mode & 4 & 5 & 3 & 3 & 3 & 3 \\
\hline
\end{tabular}

Table 7. Social strategy.

\begin{tabular}{ccccccc}
\hline & Q45 & Q46 & Q47 & Q48 & Q49 & Q50 \\
\hline N Valid & 77 & 77 & 77 & 77 & 77 & 77 \\
Missing & 0 & 0 & 0 & 0 & 0 & 0 \\
Mean & 4.09 & 4.06 & 4.10 & 3.97 & 3.58 & 3.94 \\
Median & 4.00 & 4.00 & 4.00 & 4.00 & 4.00 & 4.00 \\
Mode & 5 & 5 & 5 & 5 & 3 & 5 \\
\hline
\end{tabular}

respondents. The next Table 8 summarizes the mean value and ranks the LLSs according to the most preferred and least preferred strategy. This resembles the strategy employed the most by the artistically talented learners during second language learning.

Based on Table 9, the most preferred LLSs by artistically talented students in an art school is the metacognitive strategy that records the highest mean value followed by social strategy whereas the least preferred LLSs is compensation strategy with the lowest mean value. The other three strategies jotted average mean value. Both metacognitive and social strategies are categorized under indirect strategies based on classification made by Oxford (1990). She adds that indirect strategies are more on general management of learning. The metacognitive strategy is about coordinating the learning process meanwhile the social strategy is about learning with others. From these findings, we can see that artistically talented students are interested in managing their language learning for them to acquire the second language better. On the other hand, the least preferred strategy is compensation and it falls under direct strategies. It seems that artistically talented students are not fond of guessing or using synonyms. 
Table 8. LLSs mean value.

\begin{tabular}{ccccccc}
\hline & $\begin{array}{c}\text { Memory } \\
\text { Strategy }\end{array}$ & $\begin{array}{c}\text { Cognitive } \\
\text { Strategy }\end{array}$ & $\begin{array}{c}\text { Compensation } \\
\text { Strategy }\end{array}$ & $\begin{array}{c}\text { Metacognitive } \\
\text { Strategy }\end{array}$ & $\begin{array}{c}\text { Affective } \\
\text { Strategy }\end{array}$ & $\begin{array}{c}\text { Social } \\
\text { Strategy }\end{array}$ \\
\hline N Valid & 77 & 77 & 77 & 77 & 77 & 77 \\
Missing & 0 & 0 & 0 & 0 & 0 & 0 \\
Mean & 3.5758 & 3.7022 & 3.4978 & 3.9639 & 3.5649 & 3.9589 \\
Median & 3.4444 & 3.7143 & 3.3333 & 4.0000 & 3.5000 & 4.1667 \\
Mode & 3.22 & 3.00 & 3.00 & 3.00 & 3.50 & 4.17 \\
\hline
\end{tabular}

Table 9. LLSs rank.

\begin{tabular}{ccc}
\hline Language Learning Strategies & Mean & Rank \\
\hline Metacognitive & 3.9639 & 1 \\
Social & 3.9589 & 2 \\
Cognitive & 3.7022 & 3 \\
Memory & 3.5758 & 4 \\
Affective & 3.5649 & 5 \\
Compensation & 3.4978 & 6 \\
\hline
\end{tabular}

According to Oxford (1990), direct strategies are how the learner dealing with the new language and it requires mental processing. However, both direct and indirect strategies support each other in language learning. Leaners usually employ more than one strategy at a time during the language learning process especially Good Language Learners (GLL). It would be better if learners were able to combine direct and indirect strategies during the language learning process as propose by Oxford (1990) since the strategies support each other.

RQ 2: What are the language learning strategies used by the artistically talented students according to their art department (talent)

Table 10 will be referred to answer the second research question. There are four art departments/courses offered at Malaysian Art School. The previous research question has answered the most favorite and preferred LLSs used by artistically talented students. As for this research question, it is to identify is there any preference for LLSs usage based on the students' talent. By referring to Table 10, not all four of them agreed with each other's choice.

Dance and music students prefer social strategy as compared to metacognitive strategy and in RQ1 social strategy is ranked number 2 out of 6 strategies. This strategy allows students to learn through interaction with others. This indicates that students who are talented in dance and music able to communicate and interact with others to learn a language better. Most probably they are not the shy type of students or better known as the extrovert. This is due to high self-confidence since they have developed it well during art classes. They have performed on stage in front of audience countless times. Theatre and visual arts students prefer metacognitive strategies and this strategy records the highest mean value and 
Table 10. LLSs rank.

\begin{tabular}{|c|c|c|c|c|c|c|c|}
\hline \multicolumn{2}{|c|}{$\begin{array}{c}\text { Respondent } \\
\text { Art Department }\end{array}$} & \multirow{2}{*}{$\begin{array}{c}\text { Memory } \\
\text { Strategy }\end{array}$} & \multirow{2}{*}{$\begin{array}{c}\begin{array}{c}\text { Cognitive } \\
\text { Strategy }\end{array} \\
29\end{array}$} & \multirow{2}{*}{$\begin{array}{c}\text { Compensation } \\
\text { Strategy }\end{array}$} & \multirow{2}{*}{$\begin{array}{c}\begin{array}{c}\text { Metacognitive } \\
\text { Strategy }\end{array} \\
29\end{array}$} & \multirow{2}{*}{$\begin{array}{c}\begin{array}{c}\text { Affective } \\
\text { Strategy }\end{array} \\
29\end{array}$} & \multirow{2}{*}{$\begin{array}{c}\text { Social } \\
\text { Strategy }\end{array}$} \\
\hline & $\mathrm{N}$ valid & & & & & & \\
\hline & Missing & 0 & 0 & 0 & 0 & 0 & 0 \\
\hline \multirow[t]{5}{*}{ Dance } & Mean & 3.3793 & 3.4064 & 3.2241 & 3.6897 & 3.4943 & 3.6954 \\
\hline & Median & 3.2222 & 3.2857 & 3.0000 & 3.7778 & 3.5000 & 3.8333 \\
\hline & Mode & 3.22 & 2.79 & 3.00 & 3.00 & 3.50 & 4.17 \\
\hline & $\mathrm{N}$ valid & 14 & 14 & 14 & 14 & 14 & 14 \\
\hline & Missing & 0 & 0 & 0 & 0 & 0 & 0 \\
\hline \multirow[t]{5}{*}{ Theater } & Mean & 3.6111 & 4.0000 & 3.8571 & 4.4524 & 3.7500 & 4.1429 \\
\hline & Median & 3.4444 & 3.9643 & 3.6667 & 4.4444 & 3.6667 & 4.2500 \\
\hline & Mode & 3.22 & 3.57 & 3.33 & 4.44 & 3.50 & 4.33 \\
\hline & $\mathrm{N}$ valid & 24 & 24 & 24 & 24 & 24 & 24 \\
\hline & Missing & 0 & 0 & 0 & 0 & 0 & 0 \\
\hline \multirow[t]{5}{*}{ Music } & Mean & 3.7593 & 3.6756 & 3.4583 & 3.7824 & 3.4375 & 3.9444 \\
\hline & Median & 3.7778 & 3.7500 & 3.1667 & 3.9444 & 3.3333 & 4.0833 \\
\hline & Mode & 3.33 & 3.00 & 3.00 & 3.00 & 2.50 & 4.67 \\
\hline & $\mathrm{N}$ valid & 10 & 10 & 10 & 10 & 10 & 10 \\
\hline & Missing & 0 & 0 & 0 & 0 & 0 & 0 \\
\hline \multirow[t]{3}{*}{$\begin{array}{l}\text { Visual } \\
\text { Arts }\end{array}$} & Mean & 3.6556 & 4.2071 & 3.8833 & 4.5111 & 3.8167 & 4.5000 \\
\hline & Median & 3.6111 & 4.4286 & 4.1667 & 4.6667 & 4.1667 & 4.5833 \\
\hline & Mode & 3.44 & 4.43 & 4.17 & 3.89 & 4.17 & 5.00 \\
\hline
\end{tabular}

ranked number 1 in the RQ1 discussion. They love to coordinate the learning process by centering, arranging, planning, and evaluating their language learning process. These artistically talented students have a different experience or added value in the learning process since they learn extra art subjects as compared to mainstream students. As in this context, these students have to arrange final year art projects when they are 15 and 17 years old. This final year art project is like a concert and exhibition which will be evaluated by professional examiners and the marks will be recorded in official standardized national examination like the Malaysian Certificate of Education (SPM). During this process they have to do a lot of decision making, arranging, and planning the final year art project. It has a high similarity with metacognitive strategy. This might be the reason and relation why artistically talented students are very fond of both social and metacognitive strategies.

\section{Implication and Limitation}

Research on this field is hoped to be beneficial for the government, curriculum developers, teachers, educators, and most importantly diverse range of learners. 
As mentioned earlier this paper focuses on artistically talented ESL learners since studies on this type of learner are scarce. As indicated by Vicig (2009) the needs and experience of artistically talented students are currently unknown. The input in this paper hopefully will help teachers and ESL learners to deploy suitable and appropriate strategies that will give positive impact and improvement in learning English as a second language. Teachers can identify their students' needs by carrying surveys on preferred LLSs. Teachers can use and adapt the SILL questionnaire by Oxford to do so. Furthermore, revising teaching methods and upgrading pedagogy skills can take place after surveying to facilitate better language learning. By accommodating suitable LLSs in class, learners in return will enjoy the process. Implementing LLSs blindly without taking into consideration the students' needs might not be a successful learning process. More researches in this field will surely help teachers to realize and implement a correct and suitable process in assisting learners to learn better.

Artistically talented learners are often associated with weak or mediocre academic performances. Feasibly this study will provide a better understanding for learners even though they might not know LLSs in-depth yet answering the SILL survey will enlighten them of their LLSs preference. The task can be accomplished by identifying the most frequently used item so that they will be aware of how they acquire the second language. This will give them insights to choose and combine appropriate strategies in learning ESL therefore to achieve their intended goal such as able to communicate well and achieve a certain level of proficiency. Learners will be able to gain different learning experiences. It might be less stressful and more enjoyable compared to their previous personal experience. Hopefully, when the learners enjoy learning, they finally acquire the second language successfully. This is how LLSs help less successful learners to improve their learning experiences.

Last but not least, the data gathered can be beneficial to curriculum developers. The study provides basic information on strategies employed by artistically talented learners in acquiring a second language. By acknowledging the learners' needs, the curriculum developers can provide diverse resources and suitable teaching and learning materials. This in the end will benefit everyone that involves in the education field.

Since LLSs are proven to be effective among second language learners, more future researches should take place. Bayuong, Hashim and Yunos (2019) suggested research that covers all four language skills (reading, writing, listening, and speaking) together with grammar and vocabulary should be conducted to get sufficient data.

\section{Conclusion}

This study has concluded that the most preferred LLS used by art school ESL learners is the metacognitive strategy. There is only a slight difference in the mean value for metacognitive and social strategies. Besides, when the learners 
are divided according to their talent, two groups prefer metacognitive strategy and another two groups prefer social strategy. It can be said that most probably art school ESL learners combine these two strategies in acquiring a second language. This is supported by the data presented in the results and discussion section. On the other hand, the least preferred LLS is the compensation strategy with the lowest mean value among the 6 strategies. It can be concluded that art school ESL learners are not fond of using compensation strategies in acquiring a second language.

LLS is a wide field to be explored. Studies and researches done will help to create a concrete base that surely will become beneficial in the education sector. Despite all the findings found, still they are learners who struggle to learn and improve. Sometimes the learners are aware of the existence of LLSs and they have the motivation to support the whole learning process but still, the outcome didn't match the goal expected. This is the reason why researchers should not stop investigating and not all results can be generalized to suit any kind of learners. Assumptions can be made but to prove its effectiveness, research has to be carried out.

\section{Acknowledgements}

The authors would like to thank Universiti Kebangsaan Malaysia under the Research Grant number 1) GG-2019-077 and 2) GG-2020-027 for supporting this project.

\section{Conflicts of Interest}

The authors declare no conflicts of interest regarding the publication of this paper.

\section{References}

Bayuong, P. D., Hashim, H., \& Yunos, M. M. (2019). Identifying Language Learning Strategies Used by ESL Learners in a Rural Primary School. International Journal of Academic Research in Progressive Education \& development, 4, 151-165. https://doi.org/10.6007/IJARPED/v8-i3/6311

Chien, K. L. (2010). An Overview of Language Learning Strategies. Annual Review of Education, Communication, and Language Sciences, 7, 132-152.

Cohen, A. D. (1995). Second Language Learning and Use Strategies: Clarifying the Issues. Research Report. Revised Version.

Malaysian Ministry of Education (2020). Permohonan Sekolah Seni Malaysia 2021. https://www.permohonan.my/permohonan-sekolah-seni-malaysia-online/

O’Malley, J. M., \& Chamot, A. U. (1990). Learning Strategies in Second Language Acquisition. Cambridge: Cambridge University Press.

Oxford, R. (1990). Language Learning Strategies: What Every Teacher Should Know. Boston: Heinle and Heinle.

Oxford, R. L. (2003). Language Learning Styles and Strategies: Concepts and Relationships. IRAL, 41, 271-278. https://doi.org/10.1515/iral.2003.012 
Rahimi, M., Riazi, A., \& Saif, S. (2008). An Investigation into the Factors Affecting the Use of Language Learning Strategies by Persian EFL Learners. Canadian Journal of Applied Linguistic, 11, 31-60.

Thirasanku, J., \& Yunos, M. M. (2014). Satatus of English in Malaysia. Canadian Center of Science and Education, 10, 254-260.

Vicig, F. J. B. (2009). Accounts of the Visual Art Classroom: Catering for Artistically Talented Students. Ph.D. Thesis, Brisbane: Queensland University of Technology. 